The Practice of Oral Literary Criticism: Women's Songs in Kangra, India Author(s): Kirin Narayan

Source: The Journal of American Folklore, Vol. 108, No. 429 (Summer, 1995), pp. 243-264

Published by: American Folklore Society

Stable URL: http://www.jstor.org/stable/541878

Accessed: 09-03-2016 00:32 UTC

Your use of the JSTOR archive indicates your acceptance of the Terms \& Conditions of Use, available at http://www.jstor.org/page/ info/about/policies/terms.jsp

JSTOR is a not-for-profit service that helps scholars, researchers, and students discover, use, and build upon a wide range of content in a trusted digital archive. We use information technology and tools to increase productivity and facilitate new forms of scholarship. For more information about JSTOR, please contact support@jstor.org. 
KIRIN NARAYAN

\section{The Practice of Oral Literary Criticism Women's Songs in Kangra, India}

As early as 1966, Alan Dundes argued for the need to consider "oral literary criticism," the meanings attributed to folklore texts by the people who use them. This essay evaluates Dundes's original formulation in light of subsequent scholarly contributions, applying these to research on women's songs in Kangra, North India. I argue that honoring people's own interpretations of their folklore carries important implications for the practice of researching, writing about, and formulating folklore theory.

"ThOSE WHO DON'T HAVE TROUBLES will sing, but they won't know what they're singing about," Sangita Devi, a Brahman woman in her seventies, observed about my research on Kangra women's songs. Like many of the women I worked with, she had articulate insights on singing in general even as she issued exegeses of particular songs. Having discussed various genres of women's songs, she paused at the genre that interested me most: pakharu, about suffering in married life. "Those who do have troubles will recognize the pain," she continued, speaking Hindi. "Everyone will sing, but it's only when you know pain that you really understand the song."

As early as 1966, Alan Dundes issued a call for what he termed "oral literary criticism," or the meanings attributed to folklore texts by the people who use them. Just as a body of written literature is interpreted by a host of methods labeled as literary criticism, he reasoned, so, "for each item of folklore there is a variety of oral literary criticism" which folklorists would be well advised to elicit (1966:507). Three decades later, what has become of this insight? Why is it that scanning available literature, we still cannot locate enough cases where scholars of oral traditions have patiently sought out and respectfully reproduced extensive exegeses of particular texts from the people who use them? There have certainly been some gifted practitioners of this method, whether or not they directly derive inspiration from Dundes. ${ }^{1}$ Yet I fear that all too often we continue to be presented with folklore texts that, lacking the ballast of interpretations

Kirin Narayan is an associate professor of anthropology and South Asian studies at the University of Wisconsin-Madison

Joumal of American Folklore 108(429):243-264. Copyright (C) 1995, American Folklore Society. 
from the people studied, are dizzyingly buffeted in the crosscurrents of scholarly interpretation.

This article is an attempt to keep oral literary criticism at the forefront of folklore methodology and theory. After returning to Dundes's 1966 essay, I take its insights into my own work to piece together the meanings of a Kangra women's song, suggesting ways in which Dundes's original formulation might be systematized and extended in practice. I then reflect on the reasons that scholars might have encountered difficulties in practicing oral literary criticism. In conclusion, I address the methodological and theoretical implications of taking seriously what people have to say about their own folklore texts.

\section{Alan Dundes's Formulation}

Dundes mentions oral literary criticism in passing in two landmark essays, “Texture, Text, and Context" (Arewa and Dundes 1964:263) and "Proverbs and the Ethnography of Speaking Folklore" (Dundes 1964:73). Yet it is in "Metafolklore and Oral Literary Criticism" (Dundes 1966) that he develops the idea more fully. In that essay, Dundes acknowledges the importance of locating texts in contexts (a position that aligned him with other scholars who were then developing a performance-oriented approach). Yet he points out that context alone does not yield meaning:

\footnotetext{
The current interest in the collection of context ... has partially obscured the equally necessary and important task of collecting the meaning(s) of folklore. One must distinguish between use and meaning. The collection of context and preferably a number of different contexts for the same item of folklore is certainly helpful in ascertaining the meaning or meanings of an item of folklore. But it cannot be assumed the collection of context per se automatically ensures the collection of meaning. . . For this reason, folklorists must actively seek to elicit the meaning of folklore from the folk. [1966:506-507, emphasis in original]
}

Dundes goes on to list several planes along which indigenous meanings might be elaborated: (1) metafolklore, that is, folklore about folklore, such as a proverb about proverbs that reveals how the genre is indigenously conceived; (2) raconteurs' asides and explanatory commentary during performance; and (3) systematic exegesis from raconteurs and their audiences. Additionally, Dundes acknowledges that since symbols employed in folklore may have unconscious associations, the folk cannot always openly articulate meanings. Instead, meaning must also be pieced together through (4) the efforts of the analyst, who situates symbols from the text under consideration in light of other significant contexts in which these are employed. ${ }^{2}$

In subsequent years, Dundes contributed extensively to structuralist and psychoanalytic approaches to folklore, two paradigms that would appear to submerge individual views. While elaborating on supraindividual parameters that frame the construction of meaning-whether through patterns of thought, or developmental stages and their conflicts-Dundes continued, in his classrooms and writings, to stress the importance of eliciting interpretations from 
people who actually use folklore. In the 1976 article "Structuralism and Folklore" he reiterated his earlier call for moving beyond texts to meanings used by the people who interact with them.

There has been little concrete discussion in the folkloristics literature on precisely what different members of the audience understand by a given item of folklore even though it is clear that the same item of folklore may mean very different things to different listeners. . . One would think that the investigation of audiences and their different understandings (and misunderstandings) of folklore communication events is a likely area for further research. [1976:80]

Viewed from the vantage of the 1990s, Dundes's formulation of oral literary criticism as a fertile arena of research could be translated into the language of more recent theoretical trends in several disciplines. Rereading the 1966 essay, we are likely to see prescient traces of reader-response or reception theory, dialogical or polyphonic ethnographic authority, intertextuality, multivocality, and the argument that culture is not uniformly shared.

What obstacles might have made scholars hesitant or simply unable to incorporate the method of oral criticism into their research and writings? What insights emerge from the practice of oral literary criticism? To begin answering these questions in a concrete way, I now turn to my own research, applying Dundes's framework to one Kangra women's song so as to tease out some of the meanings overtly and implicitly ascribed to it by singers.

\section{Songs in Kangra: An Overview}

Kangra Valley lies at the foot of the towering Dhauladhar ("white bearing") Mountains of the Northwest Himalayas in India. As an administrative district, Kangra is located within the state of Himachal Pradesh. Kangra's populationreported in 1991 to be $1,149,744$-is overwhelmingly Hindu and rurally based. ${ }^{3}$ The local dialect is known as Pahāri ("of the mountains"), or more specifically as Kangri ("of Kangra”) (Sharma 1974) although many people may speak Hindi, Punjabi, and, even occasionally, English.

Across castes, village women in Kangra sing for life-cycle events. (See Figure 1.) Men may also sing devotional songs but their singing is not socially prescribed at rituals. When asked why women sing, men and women alike are likely to retort "from happiness," pointing to the conjunction of celebration and auspicious songs found throughout India (Henry 1988:110-111). Women's songs fall into a number of different-but by no means discrete-genres, largely tied to the ceremonial context in which they are sung.

In performance, one or two women who know a particular song usually lead the singing while the others follow along. Before plunging into a song, singers often confer in mutters and fragments of melody to plot out the words, the verse order, and the tune, thereby negotiating the different variants that they bring with them. Lines of text are usually repeated twice, and the melody is always 


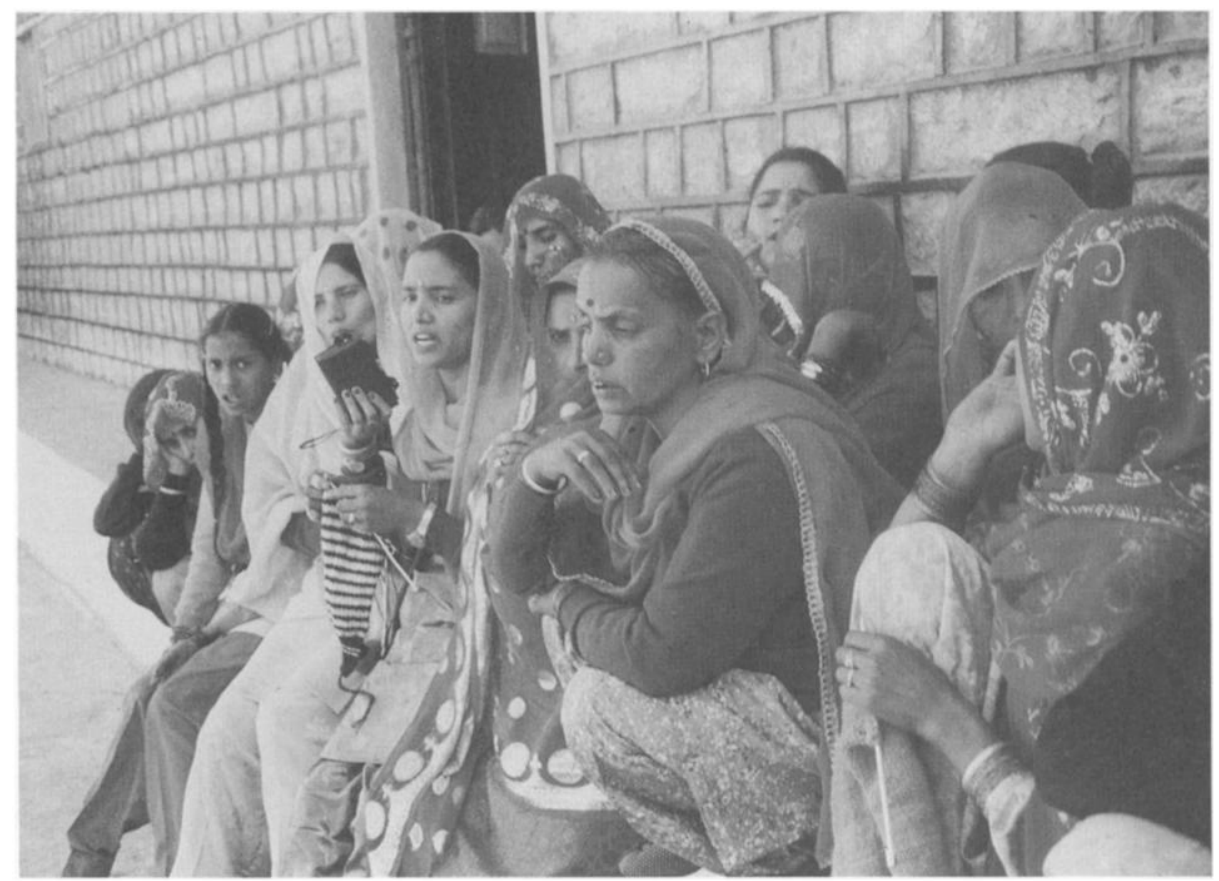

Figure 1

repetitive. This means that even a woman hearing the song for the first time is able to join in: performance is open to all who care to sing.

It is perhaps this feature of collective performance in India that appears to have blinded scholars and collectors alike to the fact that women's folksong texts might be richly interpreted by their performers. There is a vast and growing body of scholarship on women's folksongs from diverse regions of India now available in English (Archer 1985; Bryce 1961; Claus 1981; Henry 1988:25-113; Jacobson 1975; Junghare 1981; Raheja and Gold 1994; Rao 1991; Sharma 1981; Tharu and Lalitha 1991:126-142; Trawick 1988, 1991). Further, there is a rich documentation of women's songs in Indian languages all over the country, including Kangra (Randhawa 1970; "Vyathit" 1973, 1976, 1984). Though many of these studies do include contextual commentaries that link texts to women's lives in illuminating ways, none seem to elicit extended oral literary criticism from the actual performers.

The genre of song with which I am concerned here is known as pakharu. Unlike birth songs, marriage songs, and other songs tied to a ritual setting, pakharu can be sung anytime, particularly when the specific songs appropriate to a particular ritual already have been sung. Only upper-caste women sing pakharu, although women of agricultural castes have a similar genre called barsātī, which they sing while transplanting rice. Pakharu are performed in gender-segregated settings, indoors. My interest in songs often incited women to sing for me outside ritual settings, and when they did, it was pakharu that they most often sang. Men seemed largely unaware of this genre: the two times 
that I hired young men to help me with transcriptions, they commented with amazement on the tales of misery conveyed in these songs. I also found that younger, educated Kangra women usually had no knowledge of these songs. Instead, they were more attuned to exogenously based gender-representations borne into Kangra through film songs, magazines, and television. Thus, I found that the women most likely to know pakharu were most often upper caste, over 35, and semiliterate.

Girija Devi, a Brahman woman in her forties once explained pakharu to me as "songs that are long and tell a story." Indeed, pakharu have a narrative line, with the central protagonist often called "Gorie"-the beautiful one. The other defining feature of this genre is suffering $(d u k h)$. In the stories spun through songs, Gorie suffers separation from her natal home (because of village exogamy) and from her husband (because of male migration in search of jobs). She suffers mistreatment from her mother-in-law and sister-in-law (in the joint family setting), and also on occasion from her husband (a stranger on return). She longs for her mother, her brother, and intimacy with her husband. She also longs for a child of her own. In a sense, these songs form a kaleidoscopic view of married life-shifted and shaken into different patterns-envisioned for women by women. ${ }^{4}$

Though I have visited Kangra since 1975, my interest in songs dates to 1980 . As a graduate student, I documented wedding songs sung among groups of girlfriends (Narayan 1986). When I arrived for a year's fieldwork in Kangra in 1990, I was already familiar with many of the people I worked with. I tended to be viewed as a young woman sadly frozen in time: still single, forever studying. Rather than being an authority figure associated with a foreign university, I was generally treated as a pitiable girl ("poor thing") who could well use some help; older women often took emphatic charge of how I was "filling up my tapes," inviting me to collective celebrations, informally singing themselves, and also coaxing others to sing.

\section{Call Him Husband: Text, Context, Oral Literary Criticism}

On 27 June 1991, while on my rounds between villages, I stopped by to visit two sisters, Brinda Devi and Sudha, of the trader caste. The shadows were lengthening on the cobbled village paths, and the two sisters were already in the kitchen of Brinda Devi's home. Brinda Devi was a woman in her fifties, and her sister Sudha, who lived nearby, was about ten years younger. I was offered a woven mat to sit beside them on the mud floor. Soon after, a woman schoolteacher dropped in for a chat, her knitting in hand.

Like most women I had taped songs from, Brinda Devi and Sudha were curious about what others had sung. I happened to have a tape still lodged in my recorder that I had made earlier that day from Brahman women in a nearby village. Brinda Devi and Sudha, who were of a trader caste, urged me to play this tape. They listened appreciatively to one song about a married sister longing for her brother, and another about a husband who returns after 12 years only to knock aside the food that his wife has lovingly prepared for him. Both songs reminded the sisters 
of other songs that they knew. With Brinda Devi leading, they launched into one song about a brother so distressed by his married sister's plight that he advises his mother not to give birth to any more girls and becomes a wandering holy man. Since it was getting late, they said they would sing what they called "Sumba" (husband) 5 for me the next day.

I was back the next afternoon, with the sunshine bright outside. This time we went into a back bedroom. The sisters recalled that "Sumba" was very much like the song that I had previously taped, particularly because in both cases the woman prepares fennel greens for her returning husband.

"Remind me of the melody," Sudha requested of her sister. An educated schoolteacher herself, she always deferred to her semiliterate sister when it came to matters of folk knowledge.

Holding up a hand to signal that I delay taping, Brinda Devi sang a sample line, as Sudha experimented with merging in. They then nodded at me to start up my recorder, and I taped:

sumbā sumbã akhiye

ni bhaliye

sumbã giyã paradesa

bārah barie sumbã ãyã

sumbã ãyã nı bhalie

àyā khară daravār

mițț kuțți chulāh gharã

chūāh gharã ni bhaliye

kunkue de sa parauda

jhinjhaniyã kuț̣̣ı bhaṭ rınā

bhat rinã nı bhaliye

hariyã mungãdi hai dāl

soyã chirı sāg karã

sãg karã ni bhalie

hariyã mungãdi e dāl

khădi piti rusi giyã

rusi giyã nı bhalie

jãi sutã pichhvăr

kălie dholie badalie

badalie ni bhalie

baraseyã aj kanne rāt

kãlie dholie sach kittã

sach kittã nı bhaliye

baraseya aj kanne răt
Call him Husband, Husband, good woman,

Husband went abroad.

After 12 years, husband came home,

He came home, good woman,

Came and stood at the door.

Grinding earth, make a hearth,

Make a hearth, good woman

Smeared with auspicious vermillion.

Husk and cook fine rice.

Cook rice, good woman,

With green mung dal. ${ }^{6}$

Chopping fennel, make greens.

Make greens, good woman,

With green mung dal.

Eating and drinking, he got angry.

Got angry, good woman,

He set off to sleep in the backyard.

"Black and white clouds,

Oh clouds," good woman,

"Pour rain tonight."

The black and white clouds made this come true. Made this come true, good woman,

It rained this night. 
akhale sări bund pai

band pai ni bhalie

mule barâbar dhăr

hath kandolu kach manjã

kach manjã ni bhalie

diteyã bhitã ugãọ

hathe mahendi paire mahendi paire mahendı nı bhaliyã

chāviyã rahiyã paṭhār

nakharã thhatharã chhori denã

chhori denã nì bhalie

chhori deni e majãj

nakharã thhațharã kiyã chhorã

kiyã chhora nı bhaliyã

bannani teri majāj
The mortar is flooded with raindrops

Flooded with raindrops, good woman,

Heavy as pestles.

Light mattress in hand, cot under the arm,

Cot under the arm, good woman,

He tries to open the door.

\author{
"Henna on my hands, henna on my feet, \\ Henna on my feet, good man, \\ The key's in the trunk." \\ "Abandon these airs, \\ Abandon them, good woman, \\ Abandon your arrogance." \\ "Why should I abandon my airs? \\ Why abandon them, good man \\ When your arrogance must be broken?"
}

"What is it that happens in this song?" I inquired, having struggled to keep up with a transcription in my notebook.

"He had gone somewhere and came back after 12 years," Brinda Devi patiently began. "She was really happy that he'd come home after so many years. So she ground up mud and made a really beautiful hearth. Then she took kumkum [auspicious red vermillion] - what Purohits put on the forehead [in blessing]and decorated the hearth. She was so happy. Then after she'd smeared the hearth with vermillion, she pounded and husked jhinjhan, which is fine rice. Very quickly and efficiently, she pounded the rice. Then she got some greens and made green mung dãl [lentils]. She cooked all this delicious food and fed it to him. She wanted to feed him because he'd come after 12 years. He ate and drank; then he had some problem. He took his cot and put it down to sleep somewhere. In the backyard. She was really upset. 'Just look at this! I am so happy, and he just has gone off to sleep.' Great anger rose in her mind. Then she went out and looked at him sleeping in the backyard and said, 'Oh Bhagavan [God], pour down rain. Pour down such rain ...',

" 'That the drops should be like hammers, like pestles,' " put in Sudha, using the English words hammers and pestles. She grinned, white teeth flashing.

"Very long drops," said Brinda Devi, "Heavy ones. Then Bhagavan did just this. These days too [during the monsoon season], it might crackle once or twice and then rain begins to pour. In the same way, it began to pour. Then he got up carrying the cot, the cotton mattress, and the sheet. Under his arm."

"Under the arm," Sudha demonstrated with a tuck of her elbow. "Then he came and began to rattle at the door-" 
“He rattled on it,"Brinda Devi continued, raising her hand to gesture pounding, "But she was stubborn. She said, "I've put henna on my hands, henna on my feet, and the key is up in the trunk."

Sudha clapped her hands, and we all laughed. "Look at the excuse!" said Sudha. Hennaed hands, indicating a woman's auspiciousness and happiness, are especially associated with brides. Traced in a latticework of green ooze over the skin, henna must be left to dry undisturbed. Until the henna dries to reveal a rich orange stain on the skin, it temporarily incapacitates the woman who is being decorated. In this song, drying henna is appropriated to stand in as an excuse for the woman's resistance to obeying her husband. Switching to English, Sudha explained, "She's also making pretend."

" "If you were peeved, then take this!" " continued Brinda Devi. "He said, 'Don't put on airs [nakhrā] like this. It's pouring outside. Open the door. I want to come in!' "Brinda Devi gasped, like a desperate drenched man, and we all laughed again.

"She says, 'Why shouldn't I carry on like this? This was your problem, and you must experience it. Did you call it putting on airs when you went and slept out there? You have to pay for your carrying on in this way: get drenched!',

"So then he stays outside?" I asked.

Brinda Devi considered. "No, then she must have let him in."

"This is where the song ends," Sudha said.

"This sort of situation must happen a lot here," I observed after a few moments, "That a woman really serves a man with a lot of care, and a man doesn't pay any attention at all?"

Both Brinda Devi and Sudha had been vigorously nodding and clucking. "No attention at all!" echoed Brinda Devi. "Huh! This happens a lot!"

"Mostly in the past," said Sudha.

By now familiar with the way in which women's hardships in songs were frequently blamed on the past, I pressed, "So this doesn't happen now?"

"Even now women really are attentive," Brinda Devi said. "But men, there is some real arrogance in them. They don't give a damn [nah⿱一兀 mārde prabhāv]. Then that irritation burns inside a woman as rage. But what else can she do? She can't do anything about it."

What can she do? Again and again, village women telling me of painful moments in their lives would rhetorically ask, "What's to be done [kyā karnā]?" Making such statements, they were acknowledging their own relative powerlessness as dependent wives in a patriarchal social system, even as they negotiated small acts of resistance like singing subversive songs that undermined male authority (cf. Abu-Lughod 1990). A song like this seemed to speak not just to the past - as the independent professional woman Sudha asserted-but also, as Brinda Devi acknowledged, provided a commentary on contemporary social relations. Locating this particular song text amid other registers of oral literary criticism, let us see what else can be discerned about the relation between women's songs and lives in Kangra. 
So far, using Dundes's analytic framework, I have covered (2) raconteurs' asides during performance (in this case, directly after) and (3) an elicitation of oral literary criticism about a particular text through dialogue. Since the performers present also composed the audience, I could not follow Dundes's directive to separate performer and audience interpretations. I now move on to explore (1) metafolklore, or comments about folklore the frame of specified folklore genres and (4) other significant contexts that shed meaning on this particular text. Further, I will extend interpretation into an arena that Dundes does not directly discuss, although it is related to (3): commentaries about the genre as it is indigenously and intertextually conceived, which also shed light on particular texts.

At this point, since I am working with a song, I should make it clear that I am highlighting interpretations of the verbal text with only passing mention of indigenous discussions of musical meanings. This aspect, exemplified in the work of ethnomusicologists, might be called "oral musical criticism" or "language about music" (Feld 1982; Feld and Fox 1994:32-33). Furthermore, in emphasizing the meanings in this text, I am underplaying other aspects of indigenous criticism such as the evaluation of performers' competence (Briggs 1988) or style (Claus n.d.).

\section{Metafolklore}

A proverb that I have heard more than once in Kangra directly touches upon a central cultural assumption in Brinda Devi's song. "One's own woman is good even if she's cockeyed," runs this proverb, "waking each morning, you can shout for her" [apni bhali kāni, byāgah uthi hak pani]. In other words, women-and in particular wives - are expected to ungrudgingly serve their male relatives. That culturally prescribed attitudes do not subsume individual subjectivities is clear from the anger expressed by the woman in this song when her husband is inattentive to her loving service.

Two proverbs that I have found since leaving Kangra throw light instead on the practice of singing (Sharma 1974:283). One proverb, "As many cheeks, so many tunes," [jitniã khākhã titniã bākhã] seems to directly comment on women from different family backgrounds and knowledgeable in different variants, cooperating to perform together. A second proverb, "Words cost nothing but rice pancakes cost a lot" [labruā kicch ni lagdā babruā matā kich], seems to suggest that verbal action-like singing-is a sphere apart from material action. Costing nothing, and perhaps changing nothing, oral traditions are open to even those people with little social or economic clout.

When songs are mentioned within other song texts, they are usually labeled as mangal (auspicious songs) occurring in the context of weddings. The formulaic line "the girlfriends sang auspicious songs" [saiyã ne mangal gāyā] reveals an association between songs and ritual occasions, and the importance of songs in dramatizing a community of intimate women. 
A more implicit form of metafolklore emerges from the role of songs within folktales (Narayan 1996). Many folktales from this region encapsulate a few sung verses. These verses always describe a painful and poignant predicament. They are frequently a plea for help. As I will show, women's explicit testimony about sad songs reveals that they view singing as a way of letting out sorrow and finding solace. Yet evidence from folktales indicates that the medium of song can also be used as a way of requesting intervention from more powerful beings.

Who could women be addressing in songs like pakharu? Given gender segregation, it was other women who shared the painful messages of these songs. Singers often observed that songs spoke about the difficulties of different kinship roles at different stages of life (daughter, sister, wife, daughter-in-law, sister-inlaw, mother, mother-in-law, grandmother). Songs might thus serve as a plea for sympathy across generations and among stereotypically hostile female kin.

Also, sung most often at the margins of religiously focused life-cycle rituals, songs could possibly be beseeching divine intervention; some, in fact, directly invoke different gods (whose domestic troubles may be detailed in the texts). Several weeks after I had taped "Sumba" and dropped by with my Devanagri transcription to check to make sure that I had the words right, Brinda Devi commented, laughing a little, "She won, he lost! If you pray with a true heart, it will come true."

\section{Other Significant Contexts}

As Dennis Tedlock has observed, each time a person performs a folklore text, the inevitable recasting is tantamount to an order of interpretation: the way a text is performed contains an implicit commentary (Tedlock 1983:236). Further, Alan Dundes (1982), following Lévi-Strauss, has shown how comparing variants of one folklore text can illuminate how the same structural slot may be occupied by different symbolic equivalences. Variants of "Sumba," then, provide a significant context that sheds light on the text.

I found a variant of "Sumba" on a tape that, ironically, I had made at the same Brahman village in which I had taped "Foreigner Husband" [kand pardesiyā] - the song that inspired Brinda Devi and Sudha to sing "Sumba" for me in the first place. In August 1991, in the early afternoon-men off at work or napping, children off at school-a relative from a nearby house cluster had dropped in on the women of this Brahman household. This visitor, a small, sharp-featured woman in her sixties, was addressed as "Tayiji," or "Aunty." Durga Pandit, the matriarch of the household that I was visiting, and one of the most enthusiastic directors of fieldwork whom I have ever known, ordered that Tayiji sit right down, drink up some tea, and sing a few songs for my recorder, sing! After a brief hesitation, Tayiji complied, singing with a powerful vibrato that was her personal style. In this song, the word sumba is never used; instead, the husband is referred to as khaneāla (the one who eats), highlighting the importance of food as an idiom for emotion in marital relations. ${ }^{8}$ Preparing fine food is a way for a woman to show she cares: rejecting food is a way for a man 
to rebuff her affections. The song begins with the woman preparing a hearth and a nice meal. The man is disgruntled and goes off to sleep in the backyard. Here, too, the wife prays to God and the clouds pour rain. When he tries to come in the door (which on my tape appears to be "the doors of pain" [darde diyā bhitã]), the wife here does not make the excuse of the henna. She simply says that she will not open up and instructs him to "mind his words" [munh di vachan sambhāl]. She comes straight to the point of teaching him his lesson.

When she finished, Tayiji retold the story within the song. She then commented, "This is the way we are. We feel things a lot-a lot ..."

"You mean women?" I asked. Tayiji seemed to be identifying with the woman in this song whose feelings are injured.

"Women don't earn anything," she stated ambiguously. "They just sit and eat."

Durga Pandit objected in the background, "But they work hard."

I echoed, "But women also work very hard in the house." I did not add that, increasingly, some women like Sudha also worked outside the home for wages.

"Whether someone works a lot or a little, they still need something to eat," Tayiji said. "One needs ghi for one's roti [butter for one's bread]."

Tayiji's comments, which juxtapose women's sensitivity to their inability to earn, point to the fact that in Kangra as elsewhere women's household work is not valued as much as men's wage labor; lacking economic clout, women are vulnerable to the whims of the men who support them. The prevailing social arrangements that dictate that upper-caste women be married to men from distant villages, and into families of slightly higher social standing, conspire to disempower women in their marriages.

Moving beyond clearly related variants, another place to look for meaning is amid related songs. An obvious intertextuality exists here between "Sumba" and the song "Foreigner Husband," which had elicited Brinda Devi and Sudha's performance. I taped "Foreigner Husband" in five variants, but here I stick close to the version sung by Bimla Pandit that Brinda Devi and Sudha so delightedly listened to through my headphones. In this song, too, a husband returns home after 12 years (a formulaic number for separations). Here, too, the woman makes special food for him, particularly fennel greens. ${ }^{10}$ The woman goes to a nearby garden to pick these greens and is taunted by the gardener. She responds that she is the daughter and daughter-in-law of powerful men, but the wife of a "careless" [algarjiyā] husband. When she serves her husband this meal, he churlishly knocks over the plate. In anger, she goes upstairs and drinks poison. Her husband tries to rouse her, but her parting words are, "Without happiness with my in-laws, without happiness with my parents, there is no happiness in the Beautiful One's fate, oh treacherous husband."

This song is clearly linked to "Sumba": an absent husband returns home, a woman prepares special food, the man slights her, the woman is filled with rage. Yet in Bimla Pandit's song, the man is more explicitly violent, knocking over the food (in one variant he strikes her too). The woman responds by committing suicide. In some variants, her parting words are a curse on the man to never again be happy even if he should marry four more times. 
"Sumba" does not have such a tragic ending. It is more playful and erotically charged. Having spent some raucous evenings with women when men of a settlement had set off in a groom's party to fetch a bride, I knew all too well that Kangra women could revel in sexual double entendres. (On these occasions, called giddã, women often cross-dressed and brandished mock phalluses with great verve: bats, wooden spoons, rolling pins, and even the end of a long shirt pulled through the fly in trousers.) Everyday conversation, however, tended to be somewhat more restrained, and the fact that I was an unmarried woman meant that sexuality was rarely discussed in my presence.

As a result, I remained oblivious to the erotic undertones of this song until I presented a version of this article to an academic audience that included an Indian ethnomusicologist. He pointed out that the woman in this song was angry when she was sexually rebuffed by her husband, who went to sleep outside. Indeed, in Brinda Devi's commentary, the woman thinks, "Just look at this! I am so happy, and he just has gone off to sleep." Following this lead I looked again at the song and commentaries on it and could not help but notice the sexual nuances around decorated hearths, long heavy raindrops, pounding doorways, doorways, and red henna. I have no explicitly stated evidence that the door is indeed a vaginal symbol (although Tayiji's version appears to identify the door that the man pounds at as "the door of pain"). Yet, circumstantially, the association would appear to be strong. The song begins with the man standing at the doorway with a wife who fully welcomes him inside, yet ends with the man locked out by his wife when he wants to come sleep beside her. This theme of men at women's doors is echoed in other songs where the man kicks open the door, the woman turns her back in grief, and their love is said to be tarnished forever.

The wife smearing her hearth with red vermillion at the start of the song is matched by her decorating her hands with red henna at the end. Both vermillion and henna are especially associated with brides. The parting of a bride's hair is smeared with vermillion by the groom at the time of a marriage, and her hands are stained with a lacework of henna. These symbols, then, would appear to indicate celebration and an anticipation of forthcoming union. When the wife in "Sumba" decorates her hands and feet with henna, yet refuses to let her husband in until his "arrogance is broken," she seems to be asserting that her own sexuality should neither be rebuffed nor taken for granted.

Further, the moist rainy season also carries erotic overtones. In the beautiful Kangra royal-court miniatures painted in the 17 th and 18th centuries, lovers are often depicted cuddling while storm clouds fill the sky. And when I once asked a woman of the cobbler caste why women transplanting rice sang the barsāti (or "monsoon" songs, which are related to pakharu), she stated, "We sing because this is the time of marriage beween the earth and the sky."

That I, the unmarried "poor thing" in this setting, at first missed the sexual overtones in this song underscores the issue that "other significant contexts" are partly of the analyst's invention: like indigenous interpreters, we too see meanings when we are predisposed to seeing them. 
General Testimonies on the Genre

The genre of pakharu is a subset of the larger generic category git (or song). As I noted earlier, suffering in married life is intrinsic to how pakharu is locally conceived. The aesthetic of suffering (see Grima 1991) as expressed through song is spoken of by Kangra women as an important aspect of their singing, particularly when they are discussing pakharu.

A few months after I had taped "Sumba," and almost a year after Sudha had first observed me going about collecting pakharu, she stated, "Kirinji. The person who becomes a singer or storyteller is one with a lot of pain. She wants a way to express the pain. There are some things that you can't say directly, but you can say them in this form. Songs and stories become her form of solace." Brinda Devi, her older sister, looked down, intent on some wool that they were cleaning. "Do you think so too?" I asked after Sudha had elaborated on how novels could do the same thing, and a man she knew had once unburdened himself in this fictional medium although everyone knew he was really speaking of his own sorrows. Brinda Devi shrugged. As a far more prolific singer and storyteller than her younger, professionally employed sister, she had more vested in this statement as a self-description. "It could be," she noncommittally said. Knowing from village hearsay that her marriage had brought her troubles, I did not press further.

On other occasions, though, Brinda Devi could be articulate about the place of songs in her life. "Women are always singing," she once observed to me. "Whenever you go to a function [ritual gathering] women are singing. Some songs you know, and some you just sing along with. Some songs attract you, they go sit inside your heart [dil]. That's how you learn songs." Reluctant to acknowledge her past disappointments and humiliations which surface in the contents of her favorite songs, she nonetheless admitted that certain songs spoke to her above others, entering her personal repertoire. As Sangita Devi also stated: everyone might sing, but only those who had experienced similar sufferings would really engage with the song. Emotional experience was thus seen as central to the understanding that incites performance and enables interpretation.

The village postmistress, a widow of the trader caste, commented: "If there's some pain, then it comes right out of your mouth in the form of a song." Or as Narbada Upadhyaya, a Brahman woman, commented, "One is trapped by all these ties, and sometimes one's mind is filled with sorrow. Then when one sings a beautiful song, it brings happiness to the mind. All the sorrows go far away." Her sister-in-law Nirmala added, "Some thoughts come out in tears from your eyes, some come out in the form of the song." The physical act of "letting the song out" thus appears to provide comfort. Jamuna Devi, a Rajput whose husband has worked elsewhere for many years, said that with sadness "the song just begins by itself. When you're absolutely quiet, the weight grows heavier in the heart. By speaking it, it lightens a little." Similarly, Sangita Devi said, "However sad we are, whatever has happened in life, then sitting to sing, we're 
happy again." This cathartic aspect of performance is clearly related not just to the words but to the powerful musical effects of the songs.

The definition of pakharu as "songs that are long and tell a story" codes how commentaries on these songs were phrased. When explaining songs, women usually told me stories about the events being described in the song. The compact poetic form was unpacked, with interpretations about particular emotions, behavior, or circumstantial objects arising incidentally as the story was retold. In other words, "decontextualizing" the song text from its music, and "recontextualizing" it into dramatic narrative form was an illuminating indigenous order of interpretation (see Briggs and Bauman 1990). I sometimes overheard women discussing songs among themselves, particularly when one woman requested that another teach her a particular song. Most often, though, interpretations were directed at me, a partial outsider and a younger woman who required instruction.

\section{Why Scholars with the Best Intentions Sometimes Fail}

Having explored dimensions of indigenous meaning in one ethnographic setting, we are in a better position to take stock of the difficulties hindering the collection and the presentation of a people's own interpretation of their folklore. As Dundes has himself acknowledged, "It is not easy to collect oral literary criticism" (1966:509). What are some of the hindrances?

Access to people to ask about their folklore is, of course, a vital starting point for getting their opinions. Scholars working from earlier collections of fairy tales, such as Holbek (1987), have been stymied by the fact that collectors did not bother to consult narrators or audiences on meaning. Including people's own interpretations, then, involves doing fieldwork with an extant tradition in which one can be present. As Jeff Todd Titon puts it:

The text ... may reveal a certain meaning, but in performance it may have quite a different meaning. ... For the folklorist or ethnomusicologist, the beginning of understanding involves being there, listening to interpretative remarks made by the performers and moreover eliciting interpretative statements from them in conversation or dialogue. Working from the text alone is misleading. [1988:12]

Yet even if one is present in the field, not all people will be equally willing or able to provide elaborate interpretations of their songs. Many meanings may be implicit and embodied, gathering weight through performance rather than outright exegesis. Lila Abu-Lughod, for example, writes that in her study of the Bedouin ghinnāwa poems, "most women were not able to explain poems to me. When I asked what a poem meant, they simply repeated the words or described the type of situation that might elicit the poem" (1986:27). Similarly, in studying Spanish tales of courtship, Taggart states, "Narrators generally did not offer many clues when asked to interpret their own stories" (1990:9). Some performers may even go so far as to bluntly criticize the scholarly quest for meaning. 
Reminiscing about her childhood, when her lifelong love of ballads first took root, Almeda Riddle observed to Roger Abrahams:

\begin{abstract}
Of course "folklore," the word was not even known then. Nobody knew anything about that, which probably was a very happy situation. I think so, because maybe if we didn't try to go so deeply, I think we might enjoy what we have more. We're becoming entirely too technical in this thing. We're trying to pick it apart. I believe that. And I think that folksongs are meant more or less like children: you're not meant to try to understand them or analyze them, just to enjoy them. [1970:132]
\end{abstract}

Dundes comments on a position similar to Almeda Riddle's- "the popular belief that analysis of a work of art interferes with or ruins one's enjoyment of it" (1966:514). He ascribes this to the unconscious, frequently tabooed meanings that reside in folklore texts, pointing out that "if the folk consciously recognized the symbolic significance of the joke or folksong element, this element might not be able to continue to serve as safe, socially sanctioned outlet" (1966:514). Bruno Bettelheim has also argued for the importance of unconscious expression through folklore: if the boys and girls who enjoy fairytales knew what these expressed about their conflicts, he writes, it would detract from the stories' therapeutic significance (1976:18). James Taggart shares this opinion, asserting at the start of his book on Spanish folktales that "their metaphorical meaning is often unconscious or subconscious and the storytellers prefer to reflect on themselves through storytelling rather than in the direct description of their deeply personal experiences. Speaking in the metaphorical language of a story allows them to express deep feelings through the safety of fantasy" (1990:9).

While I agree that veiled or unconscious release may be a potent factor in why people use folklore, I would nonetheless challenge the next step that such views can imply. Taggart, for one, continues: "consequently, the language of stories invites many interpretations, which vary with the theoretical framework of the interpreter" (1990:9). In other words, too close an adherence to this position can whisk away the possibility of interpretation from the people who actually use folklore texts, keeping the prerogative solely for a literate interpreter with many theoretical frameworks at his or her command. As Taggart moves through interpretations of memorable fairy tales, one wishes that he had occasionally paused to check on his hunches for interpretation-as Peter Seitel does with the Haya storyteller, Ma Winifred Kisiraga (Seitel 1980:34)-or allow narrators the space to elaborate on the larger cultural context-like Harold Scheub in his collaboration with the South African storyteller Nongenile Masithathu Zenani (Zenani 1992).

Apart from remaining unspoken because of their assumed or unconscious nature, meanings may remain unelaborated because of their subversive potential. As the historian James Scott has observed, "Oral traditions, due simply to their means of transmission, offer a kind of seclusion, control, and even anonymity that makes them ideal vehicles for cultural resistance" (1990:160). In other words, people can distance themselves from the folklore that they use ("that's 
just a joke," or "I didn't make it up") even as they draw on folklore forms to express how they perceive a social situation. Roger Abrahams's insight that folklore has a strategic interpersonal value as "an implement for argument, a tool for persuasion" (1968:146) would be lost if a person were to ploddingly enumerate just why they said something, and what exactly it meant for the situation at hand.

Where exegeses of particular texts may be thwarted by unconscious or interpersonal blocks, testimonies on a genre can allow a speaker to speak in generalities that can conceal uncomfortable meanings or motives. Like metafolklore, such general comments appear to provide a protective cover for motives and meanings residing in particular texts for individual performers. Lila Abu-Lughod's (1986) careful incorporation of generalized comments from Bedouin men and women about the genre of ghinnãwa poems, as well as her location of these poems in the context of unfolding social life structured by the values of honor and modesty, sheds light on the genre as a whole and thus on particular poems. Similarly, Granny Riddle's caution against analysis of particular songs is balanced by her love of talking generally about what songs have meant to her through her difficult life in rural Arkansas and the ways she associates particular songs with the people she learned them from (Abrahams 1970). Or, moving to my own work on the stories of Swamiji, a Hindu holy man, while I was unable to always elicit commentaries on particular stories, his listeners were eloquent on what stories in general meant to them (Narayan 1989). The methodology of oral literary criticism, then, could be profitably opened up beyond the exegesis of particular texts to discussions of the genre along the various ways it is indigenously, intertextually defined (see Briggs and Bauman 1992).

The presence of scholars who do not automatically share the cultural meanings encoded in folklore texts may actively trigger interpretations that would not otherwise be voiced. Just as folklore performances, like stories, frequently feature asides to clue in an audience (Basgöz 1986; Georges 1983), so the presence of a researcher in that audience may evoke explicit commentary. The more a folklore event is demarcated as separate from conversational process, the more explicit help an alien observer will require in interpreting the meanings of an event to its participants (Tedlock 1983:300).

While the researcher's ignorance may stimulate oral literary criticism, at the same time, a researcher must learn culturally appropriate ways of asking questions (Briggs 1986). The strategies used by people themselves in their commentaries on folklore may reveal the contours of a shared cultural style of interpretation and uncover the differences between community-based orientations (Errington 1984; George 1993). Further, as Peter Claus (n.d.) has shown in his work on Tulu ballads (pāḍdanā), oral literary criticism may not just mean symbolic explication but rather an evaluation of performative style and textual variation. Dealing with Kangra songs, for example, I soon found that asking about "the meaning" of constituent symbols met with no response. Reframing 
my question to ask what was happening in the song, however, usually evoked a long narrativized interpretation.

Assuming that people are willing to issue interpretations at all, a fieldworker is likely to encounter variation in the perspectives and articulateness of different individuals (Dundes 1966:515). Social consensus-in this case, people cooperating on the performance of a text-by no means indicates symbolic consensus, or agreement on meanings (Fernandez 1965). Each interpretation, as Edward Sapir argued, has "a special kind of rightness . . partly factual, partly personal" (1968:574); all these interpretations are likely to be framed within cultural idioms that may be unequally shared. A researcher then must have the patience to ask the same question again and again, acquiring different points of view.

Further, a researcher must take heed when people themselves defer to certain specified individuals for interpretation. In Kangra, I was repeatedly directed to certain women who others described as being "very knowledgable" [bari gyānī]-Brinda Devi was one of these. Henry Glassie describes such individuals as "those thinkers who have cracked convention into principle" and whose "less articulate neighbors have granted them power to speak" (1982:643). Whether such locally appointed "oral literary critics" derive their authority from specified social roles (such as Brahman priest, or Guru), stages of life (old woman), or personal inclination is another illuminating angle for us to consider.

\section{Conclusion: Methodological and Theoretical Implications}

Alan Dundes's inspired 1966 call to take oral literary criticism seriously continues to have powerful implications for the practice of researching, writing about, and theorizing folklore. I have grappled with these issues in my own work, and here are some of the consequences I discern.

In terms of field research, consulting people on meaning sets high standards of ethics and commitment. It demands that a researcher strive for enough facility in a language (or languages) to make dialogue possible. Rather than sailing in to document a folklore performance that can be transcribed and analyzed from afar, a scholar must nurture relationships so as to be worthy of trust when people are ready to speak, to relearn ways of asking, and to be attentive to silences. The title "informant," which emphasizes the plane of information-spewing as the most significant aspect of identity among the people with whom we work, becomes sadly inadequate. Striving to know people in their complexity invites a scholar to enquire into the sociological, economic, and cultural constraints that frame their lives and, by extension, their production and interpretation of folklore.

In terms of writing, taking oral literary criticism seriously involves a shift in ethnographic representation. Instead of writing in terms of a generalized, flattened, collective subject ("the folk," "the natives," "the Kangra woman"), we are forced to portray individuals with unequal access to material and symbolic resources, and with possibly divergent points of view. Further, dialogue that is so central to the construction of meaning between the people studied and the 
scholar also becomes prominent in written texts (Dwyer 1982; Tedlock 1983). Rather than issuing summaries of meaning, it is necessary to make clear which interpretations were voiced by indigenous experts and which emerged from the discourse of scholarship. It is in the nature of scholarship to connect other people's words with academically forged theoretical frameworks, yet keeping the two levels distinct surely makes for more honest written productions. As Margaret Mills succinctly states in her study of Afghan storytelling, "we must ... confront the fact that our interpretive procedures will remain far different from those indigenous to the social habitat of the stories" (1991:23).

Jeff Todd Titon has argued that interpretation be viewed as open-ended, advocating that a folklorist return to the people studied "not to do "follow up fieldwork' and verify conclusions, but to continue the dialogue, knowing that the conclusions will never be conclusive" (1988:13). Elaine Lawless and Katherine Borland draw inspiration from feminist methodology to push these ongoing processes of dialogue into the arena of responses to a scholar's written texts from the people described in them (Borland 1991; Lawless 1991, 1992). Their contributions remind us that oral literary criticism can be useful not only in terms of the interpretations of orally produced indigenous texts but also as a critical form of "reader-response" to scholarly texts that are written down.

Theoretically, including interpretations from different individuals forces us to see that, just as culture is not a system of uniformly shared meanings, so folklore is not equally shared by the folk. As Roger Keesing eloquently argued:

Meanings, or at least many of the deeper meanings a symbolist would want to uncover, are not
there as part of the text. . . Meanings, we might better say, are not in the cultural texts, not
inherent in cultural symbols, but evoked by them. Some meanings are shared and public, others
are not. They are, to change the image back again, deeper layers of the onion. What symbols
mean to native actors depends on what they know. [Keesing 1987:164, emphases in the original]

Eliciting oral literary criticism breaks down the assumption that meanings, texts, and actors are all indivisibly bound together. To take seriously what "the folk" do with and say about their folklore involves viewing artistic productions like folklore texts not just as cultural objects but as practices by positioned subjects (Williams 1991:421-422). It induces us to grant the people we work with respect as complex subjects who know some things and not others, and also as agents who are in a position to actively embroider meanings around texts. It reminds us that "interpretation" as a category may take different forms-based on cultural style, social identification, individual predilection, and so on-and that it is often partially a product of a relationship with a researcher.

Among the manifold intellectual and interpersonal rewards of taking oral literary criticism seriously, the most vital, I believe, lies in reconceptualizing so-called informants. The people we work with clearly do not exist just to mechanically issue materials for scholarship. They are reflective, playful, and unpredictable human beings who, collaborating on the analyses of these materials, may also educate scholars. 
The phase of research on which this essay is based took place between September 1990 and September 1991, thanks to the support of the University of Wisconsin Graduate School Funds, an American Institute of Indian Studies Senior Fellowship, and a National Endowment for the Humanities Fellowship. Time for writing has been provided for by the School of American Research, a John Simon Guggenheim Foundation Fellowship, and a Social Science Research Council Fellowship. I am extremely grateful to all these granting agencies for their generosity.

My thanks to Eytan Bercovitch, John Bendix, Regina Bendix, Peter Claus, Ken George, Margaret Mills, Narayana Rao, Paul Stoller, and Elizabeth Tolbert for critical comments on this article in its current incarnation. For illuminating comments on earlier or oral versions, thanks to Alan Dundes, Kevin Dwyer, Robert Georges, Elvin Hatch, Nazir Jairazbhoy, Maria Lepowsky, Sabina Magliocco, Mattison Mines, and Joseph Nagy. My enduring thanks remains with my friends in Kangra. An earlier version that includes the musical text-for logical reasons not included here-will appear in The Interpretation of Folklore: Essays in Honor of Alan Dundes, ed. Regina Bendix and Rosemary Zumwalt, forthcoming from Garland Press.

${ }^{1}$ Marcel Griaule's Conversations with Ogotemmêli (1965), which records interpretations of Dogon myth by a tribal elder, remains a classic, as do the vivid essays on Zuni and Quiché understandings of mythology by Dennis Tedlock in The Spoken Word and the Work of Interpretations (1983). Other exemplary works in which folklore texts are enriched by oral literary criticism include Kay Stone's (1985) analysis of American men and women interpreting the Cinderella story, Henry Glassie's (1982) portrayal of Irish peasants explaining their local traditions, Linda Hess's discussion of the audience reception of Ramlila theatrical performances in Banaras (1983), Keith Basso's vivid depiction of Western Apaches discussing place names (1984), and Peter Claus's discussions on the evaluation of performance style and textual variation with the Tulu singer Kargi (n.d.).

2Dundes's methodology for folklore texts complements Victor Turner's methodology for the analysis of ritual symbols, where meaning is worked out from laypeople, exegetes, and other important contexts gathered together by the anthropologist (Turner 1967:20-27).

${ }^{3}$ For more on the ethnography of Kangra, see Campbell 1976, Parry 1979, and U. Sharma 1980 and 1981.

${ }^{4}$ The Kangra folklorist Gautam Vyathit has linked the word pakharu to pakhaṛ ḍā, the daily worship of the courtyard that married village women perform with cowdung and sprinkled leaves. "In this context," he writes, "pakharu as songs of complaint are like leaves which before giving birth to flowers have experienced sorrow and pain" (Vyathit 1973:129).

${ }^{5}$ Sumbā is a word for husband, which like kand and ḍholā occurs largely in song texts. Among the other terms for husband I found in pakharu are "employed man" (naukar, chākar), "traveler" (musāphara), or "soldier" (sipāhI). Further, the mythological divinities in human form, Ram and Shyam (Krishna), as ideal men can also indicate husbands in the songs.

${ }^{6}$ Brinda Devi and Sudha's eldest sister, visiting some months later, amended this verse to go:

soyã chirì sāg rinā

Chop fennel leaves and simmer greens.

sāg rinā ni bhalie elaichie de liyār Simmer greens, good woman Sprinkle with cardamom.

${ }^{7}$ Tayi literally means father's elder brother's wife, although in this case it is used in a general sense of senior female relative from a related housecluster in the same village.

${ }^{8}$ The melody of these two songs is very similar, but the line order is such that line one is repeated in line three rather than, as with Sumba, in line two. For example, in Brinda Devi's song, the sixth verse runs:

khādi pidi rusi giyã rusi giyā nì bhalie jāi sutā pichhvār
Eating and drinking, he got angry.

Got angry, good woman,

He set off to sleep in the backyard. 
But Tayiji's text has:

khaneaalā rusi giyã aḍhiyã jāi sutā o pichvãr khaneãlā rusi giyã
The one who eats got angry

Friend, he went off to sleep in the backyard.

The one who eats got angry.

${ }^{9}$ Unfortunately I was not able to check this point with Tayiji.

${ }^{10}$ No matter how much I asked about the symbolic importance of fennel greens (soyã da sāg) or what else they were used for, all I learned was that this was considered a delicacy and not eaten often.

\section{References Cited}

Abrahams, Roger D. 1968. Introductory Remarks to a Rhetorical Theory of Folklore. Journal of American Folklore 81:143-158.

1970. A Singer and Her Songs: Almeda Riddle's Book of Ballads. Baton Rouge: Louisiana State University Press.

Abu-Lughod, Lila. 1986. Veiled Sentiments: Honor and Poetry in a Bedonin Society. Berkeley: University of California Press.

1990. The Romance of Resistance: Tracing Transformations of Power through Bedouin Women. American Ethnologist 17:41-55.

Archer, William G. 1985. Songs for the Bride: Wedding Rites of Rural India. Edited by B. S. Miller and M. Arche. New York: Columbia University Press.

Arewa, E. Ojo, and Alan Dundes. 1964. Proverbs and the Ethnography of Speaking Folklore. In The Ethnography of Communication, ed. John J. Gumperz and Dell H. Hymes. Special issue, American Anthropologist 66(6, part 2):70-85.

Basgöz, Ilhan. 1986. Digression in Oral Narrative: A Case Study of Individual Remarks by Turkish Romance Tellers. Journal of A merican Folklore 99:5-23.

Basso, Keith. 1984. Stalking with Stories: Names, Places, and Moral Narratives among the Western Apache. In Text, Play, and Story, ed. E. M. Bruner, pp. 19-55. Washington, D.C.: American Ethnological Society.

Bettelheim, Bruno. 1976. The Uses of Enchantment: The Meaning and Importance of Fairy Tales. New York: Alfred A. Knopf.

Borland, Katherine. 1991. "That's Not What I Said": Interpretive Conflict in Oral Narrative Research. In Women's Words: The Feminist Practice of Oral History, ed. S. B. Gluck and D. Patai, pp. 63-75. New York: Routledge.

Briggs, Charles. 1986. Learning How to Ask. Cambridge: Cambridge University Press. 1988. Competence in Performance: The Creativity of Tradition in Mexicano Verbal Art.

Philadelphia: University of Pennsylvania Press.

Briggs, Charles, and Richard Bauman. 1990. Poetics and Performance as Critical Perspectives on Language and Social Life. Annual Review of Anthropology 19:59-88. Genre, Intertextuality, and Social Power. Journal of Linguistic Anthropology 2:131-172.

Bryce, Winifred. 1961. Women's Folk Songs of Rajputana. New Delhi: Ministry of Information on Broadcasting, Government of India.

Campbell, Gabriel. 1976. Saints and Householders: A Study of Hindu Ritual and Myth among the Kangra Rajputs. Kathmandu: Ratna Pustak Bhandar.

Claus, Peter. 1991. Kin Songs. In Gender, Genre and Power in South Asian Expressive Traditions, ed. A. Appadurai, F. J. Korom, and M. Mills, pp. 136-177. Philadelphia: University of Pennsylvania Press.

n.d. Folk Literary Criticism and the Tulu Paddana Tradition. Unpublished manuscript. Clifford, James. 1988. The Predicament of Culture. Cambridge, Mass.: Harvard University Press. Dundes, Alan. 1964. Texture, Text and Context. Southern Folklore Quarterly 28:251-265. 1966. Metafolklore and Oral Literary Criticism. The Monist 60:505-516. 1976. Structuralism and Folklore. Studia Fennica 20:75-93. 
1982. The Symbolic Allomotifs in the Rabbit Herd (AT 570). ARV: Scandinavian Yearbook of Folklore 36:91-98.

Dwyer, Kevin. 1982. Moroccan Dialogues: Anthropology in Question. Baltimore, Md.: Johns Hopkins University Press.

Errington, Frederick. 1984. Manners and Meanings in West Sumatra: The Social Context of Consciousness. New Haven, Conn.: Yale University Press.

Feld, Steven. 1982. Sound and Sentiment: Birds, Weeping, Poetics and Song in Kaluli Expression. Philadelphia: University of Pennsylvania Press.

Feld, Steven, and Aaron A. Fox. 1994. Music and Language. Annual Review of Anthropology 23:25-53.

Fernandez, James. 1965. Symbolic Consensus in a Fang Reformative Cult. American Anthropologist 67:902-929.

George, Kenneth M. 1993. Lyric, History and Allegory; or the End of Headhunting Ritual in Upland Sulawesi. American Ethnologist 20:696-716.

Georges, Robert A. 1983. Do Narrators Really Digress? A Reconsideration of Audience Asides in Narrating. Western Folklore 40:215-242.

Glassie, Henry. 1982. Passing the Time in Balleymenone. Philadelphia: University of Pennsylvania Press.

Griaule, Marcel. 1965. Conversations with Ogotemmêli: An Introduction to Dogon Religious Ideas. London: Oxford University Press.

Grima, Benedicte. 1991. The Role of Suffering in Women's Performance of Paxto. In Gender, Genre and Power in South Asian Expressive Traditions, ed. A. Appadurai, F. J. Korom, and M. Mills, pp. 81-101. Philadelphia: University of Pennsylvania Press.

Henry, Edward. 1988. Chant the Names of God: Music and Culture in Bhojpuri-Speaking India. San Diego, Calif.: San Diego State University Press.

Hess, Linda. 1983. Ramlila: The Audience Experience. In Bhakti in Current Research, ed. Monika Thiel-Horstmann, pp. 171-294. Berlin: Dietrich Reimer.

Holbek, Bengt. 1987. Interpretation of Fairy Tales. Helsinki: Suomalainen Tiedeakatemia.

Jacobson, Doranne. 1975. Songs of Social Distance. Journal of South Asian Literature 9:45-160.

Junghare, Indira. 1981. The Position of Women as Reflected in Marathi Folk Songs. Man in India 61:237-253.

Keesing, Roger. 1987. Anthropology as Interpretive Quest. Current Anthropology 28:161-176.

Lawless, Elaine J. 1991. Women's Life Stories and Reciprocal Ethnography as Feminist and Emergent. Journal of Folklore Research 8:35-60.

1992. "I Was Afraid Someone Like You ... an Outsider . . Would Misunderstand": Negotiating Interpretive Differences between Ethnographers and Subjects. Journal of American Folklore 105:302-314.

Mills, Margaret. 1991. Rhetorics and Politics in Afghan Traditional Storytelling. Philadelphia: University of Pennsylvania Press.

Narayan, Kirin. 1986. Birds on a Branch: Girlfriends and Wedding Songs in Kangra. Ethos 14:47-75. 1989. Storytellers, Saints, and Scoundrels: Folk Narrative in Hindu Religious Teaching. Philadelphia: University of Pennsylvania Press.

1996. Earth into Gold: Himalayan Foothill Folktales Told by Urmila Devi Sood. Oxford University Press (in press).

Parry, Jonathan. 1979. Caste and Kinship in Kangra. London: Routledge and Kegan Paul.

Raheja, Gloria Goodwin, and Ann Grodzins Gold. 1994. Listen to the Heron's Words: Reimagining Gender and Kinship in North India. Berkeley: University of California Press.

Randhawa, M. S. 1970[1963]. Kãngrã: Kal, Lok te Geet [Kangra: Art, Folk, and Song]. Delhi: Attarchand Kapurchand.

Rao, Narayana. 1991. A Ramayana of Their Own: Women's Oral Tradition in Telugu. In Many Ramayanas, ed. Paula Richman, pp. 114-136. Berkeley: University of California Press.

Sapir, Edward. 1968. Why Cultural Anthropology Needs the Psychiatrișt. In Selected Writings of Edward Sapir, ed. David Mandelbaum, pp. 569-577. Berkeley: University of California Press. 
Scott, James. 1990. Domination and the Arts of Resistance. New Haven, Conn.: Yale University Press. Seitel, Peter. 1980. See So That We May See: Performances and Interpretations of Traditional Tales from Tanzania. Bloomington: Indiana University Press.

Sharma, Shyamlal. 1974. Kãngari: A Descriptive Study of the Kangra Valley Dialect of Himachal Pradesh. Hoshiarpur, Panjab: Vishveshvaranand Vishva Bandhu Institute of Sankrit and Indological Studies Press.

Sharma, Ursula. 1980. Women, Work and Property in North West India. London: Tavistock. . Women's Songs in Rural Punjab. Cahiers de Littêrature Orales 6:41-70.

Stone, Kay F. 1985. The Misuses of Enchantment: Controversies on the Significance of Fairy Tales. In Women's Folklore, Women's Culture, ed. R. Jordan and S. J. Kalčik, pp. 125-145. Philadelphia: University of Pennsylvania Press.

Taggart, James. 1990. Enchanted Maidens: Spanish Folktales of Courtship and Marriage. Princeton, N.J.: Princeton University Press.

Tedlock, Dennis. 1983. The Spoken Word and the Work of Interpretation. Philadelphia: University of Pennsylvania Press.

Tharu, Susie, and K. Lalitha. 1991. Women Writing in India: 600 B.C. to the Present, Vol. I. New York: Feminist Press.

Titon, Jeff Todd. 1988. Powerhouse for God: Speech, Chant and Song in an Appalachian Baptist Church. Austin: University of Texas Press.

Trawick, Margaret. 1988. Spirits and Voices in Tamil Song. American Ethnologist 15(2):193-215. . 1991. Wandering Lost: A Landless Laborer's Sense of Place and Self. In Gender, Genre and Poiver in South Asian Expressive Traditions, ed. A. Appadurai, F. J. Korom, and M. A. Mills, pp. 224-266. Philadelphia: University of Pennsylvania Press.

Turner, Victor. 1967. The Forest of Symbols: Aspects of Ndembu Ritual. Ithaca, N.Y.: Cornell University Press.

Vyathit, Gautham Sharma. 1973. Kangri Lok Git [Kangra Folk Songs]. Palanpur, India: Sheela Prakashan.

1976. Jhume DhartI Gãe Lok [Swaying Earth, Singing Folk]. Palanpur, India: Sheela Prakashan.

. 1984. Kāngrăā ke Lokgit: săhityik vishleshan evam mulyānkan [Kangra’s Folksongs: A Literary Analysis and Estimation]. [Dehli, India]: Jayshree Prakashan.

Williams, Raymond. 1991. Base and Superstructure in Marxist Cultural Theory. In Rethinking Popular Culture, ed. C. Mukerji and M. Schudson, pp. 407-423. Berkeley: University of California Press.

Zenani, Nongenile Masithathu. 1992. The World and the Word: Tales and Observations from the Xhosa Oral Tradition. Edited by Harold Scheub. Madison: University of Wisconsin Press. 